\title{
Memory complaints at primary care in a middle-income country: clinical and neuropsychological characterization
}

\author{
Marcos Leandro Pereira',2 ${ }^{1}$, Thiago Henrique Ferreira de Vasconcelos ${ }^{\circledR}$, Amanda Aparecida Rocha de \\ Oliveira ${ }^{\odot}$, Sarah Bárbara Campagnolo ${ }^{\circ}$, Sarah de Oliveira Figueiredo ${ }^{\circledR}$, Ana Flávia Bereta Coelho \\ Guimarães $^{2}{ }^{\oplus}$, Maira Tonidandel Barbosa ${ }^{\oplus}$, Luís Felipe José Ravic de Miranda ${ }^{\oplus}$, Paulo Caramelli ${ }^{1,4} \odot$, \\ Leonardo Cruz de Souza ${ }^{1,4}$ ๑
}

\begin{abstract}
There are different causes of memory complaints in the elderly, such as subjective cognitive decline (SCD), mild cognitive impairment (MCl) or dementia. Objective: 1) To characterize individuals with memory complaints in a mid-sized city in Brazil, through clinical, cognitive and functional assessment; 2) to compare SCD individuals with $\mathrm{MCl}$ and dementia patients in terms of clinical and cognitive variables. Methods: We consecutively included individuals aged $\geq 50$ years, with memory complaints (spontaneous or inquired). Subjects who scored $\geq 25$ on the Memory Complaint Questionnaire or who had spontaneous memory complaints were selected. Participants underwent a semi-structured interview, the Mini-Mental State Examination, Figure Memory Test for visual episodic memory, Clock Drawing Test, Category Fluency (Animals), Neuropsychiatric Inventory, and functional assessment. Individuals were classified as SCD, MCl or dementia. We did not include individuals with previous diagnosis of dementia. Results: The final sample consisted of 91 subjects (73.6\% women; mean age 67.6 \pm 9.8 years): $14.3 \%$ had spontaneous complaints and $85.7 \%$ had inquired complaints. The most common comorbidities were hypertension (69.2\%), diabetes (36.3\%), and dyslipidemia (24.2\%). Low levels of vitamin B12 and hypothyroidism were found in 26.4 and $16.5 \%$, respectively. Regarding cognitive diagnosis, $16.5 \%$ of the sample were classified as SCD, $49.4 \%$ as $\mathrm{MCl}$ and $34.1 \%$ as dementia. MCl and dementia were identified in five (38.5\%) and seven (53.4\%) patients with spontaneous complaint, respectively. Conclusions: $\mathrm{MCl}$ and dementia are frequently underdiagnosed. Potential reversible causes of cognitive decline are common. The diagnosis of dementia is highly frequent among individuals with spontaneous memory complaints.
\end{abstract}

Keywords: memory, primary health care, cognitive dysfunction, dementia.

QUEIXAS DE MEMÓRIA NA ATENÇÃO PRIMÁRIA EM UM PAÍS DE RENDA MÉDIA: CARACTERIZAÇÃO CLÍNICA E NEUROPSICOLÓGICA RESUMO. Há diferentes causas de queixas de memória nos idosos, como declínio cognitivo subjetivo (DCS), comprometimento cognitivo leve (CCL) ou demências. Objetivo: 1) Caracterizar indivíduos com queixa de memória em uma cidade de médio porte do Brasil, por meio de avaliação clínica, cognitiva e funcional; 2) comparar indivíduos com DCS, com CCL e pacientes com demência em termos de variáveis clínicas e cognitivas. Métodos: Incluiu-se, de modo consecutivo, indivíduos com idade $\geq 50$ anos, com queixas de memória (espontânea ou inquirida). Foram selecionados participantes que pontuaram $\geq 25$ no Questionário de Queixa de Memória ou que apresentaram queixa de memória espontânea. Todos foram submetidos à entrevista semiestruturada, Miniexame do Estado Mental, Teste de Figuras (teste de memória episódica visual), Teste do Desenho do Relógio, Fluência Semântica (Animais), Inventário Neuropsiquiátrico e avaliação funcional. Os indivíduos foram classificados em declínio cognitivo subjetivo (DCS), CCL e demência. Resultados: A amostra final foi composta por 91 indivíduos (73,6\% mulheres; média de idade 67,6 $\pm 9,8$ anos); $14,3 \%$ apresentaram queixa espontânea e 85,7\%, queixa inquirida. As comorbidades mais comuns foram hipertensão $(69,2 \%)$, diabetes $(36,3 \%)$ e dislipidemia (24,2\%). Baixos níveis de vitamina B12 e hipotireoidismo foram encontrados em 26,4 e 16,5\%, respectivamente. Quanto ao diagnóstico cognitivo, 16,5\% foram classificados como DCS, 49,4\% como CCL e 34,1\% como demência. CCL e demência foram respectivamente identificados em cinco $(38,5 \%)$ e sete $(53,4 \%)$ pacientes com queixa espontânea de memória. Conclusões: CCL e demência são frequentemente subdiagnosticados. Causas potencialmente reversíveis de declínio cognitivo foram frequentes na amostra. 0 diagnóstico de demência foi muito frequente entre indivíduos com queixas espontâneas de memória.

Palavras-chave: memória, atenção primária à saúde, comprometimento cognitivo, demência.

\footnotetext{
This study was conducted at the Patos de Minas, Minas Gerais, Brazil.

1Programa de Pós-Graduação em Neurociências, Universidade Federal de Minas Gerais - Patos de Minas, MG, Brazil.

${ }^{2}$ Curso de Medicina, Centro Universitário de Patos de Minas - Patos de Minas, MG, Brazil.

${ }^{3}$ Curso de Psicologia, Centro Universitário de Patos de Minas - Patos de Minas, MG, Brazil.

${ }^{4}$ Departamento de Clínica Médica, Faculdade de Medicina, Universidade Federal de Minas Gerais - Belo Horizonte, MG, Brazil.

Leonardo Cruz de Souza. Faculdade de Medicina, Universidade Federal de Minas Gerais. Avenida Professor Alfredo Balena, 190/sl 243 - Centro - 30130-100 Belo Horizonte MG - Brazil. E-mail: leocruzsouza@ufmg.br

Disclosure: The authors report no conflicts of interest.

Funding: none.

Received on June 23, 2020. Accepted in final form on October 26, 2020.
}

\section{(cc) BY}




\section{INTRODUCTION}

Cognitive complaints are frequent among older adults. ${ }^{1}$ Some cognitive functions tend to decrease with age, such as attention and executive functions. ${ }^{2}$ During normal aging, episodic memory may also be affected by encoding or recall deficits, which depend on executive functions. ${ }^{3}$ Indeed, declining processing speed, reduced processing resources, and decreased cognitive control may account for age-related memory complaints. ${ }^{2}$

On the other hand, memory loss is a frequent symptom in different neuropsychiatric disorders, including dementias and psychiatric disorders, ${ }^{4}$ and is also found in systemic conditions (e.g., hypothyroidism and vita$\min$ B12 deficiency). ${ }^{5}$

Previous studies investigated the prevalence of memory complaints in different populations. The frequency of memory complaints is variable across studies, ranging from 8 to $50 \% .^{6-8}$ Older age, female sex, depressive and anxious symptoms and low educational level are generally associated with a higher prevalence of memory complaints..$^{3,9,10}$ Moreover, memory complaints can predict dementia, particularly in patients with mild cognitive impairment (MCI). ${ }^{11,12}$ Despite their clinical relevance, memory complaints are not always reported to the general practitioner. ${ }^{12}$

Complaints of memory loss may be associated with subjective cognitive decline (SCD), which is currently defined by two hallmark features: 1 ) self-experience of continuous deterioration in cognitive status, in comparison with the individual's preceding level and; 2) normal performance on standardized neuropsychological tests, considering education, age and gender. ${ }^{13} \mathrm{SCD}$ is not merely an age-related phenomenon but is recognized as an important risk factor for $\mathrm{MCI}$ and Alzheimer's disease (AD) ${ }^{14}$

Considering that cognitive disorders may be due to reversible causes, it is crucial that health professionals perform proper cognitive screening at primary care. Moreover, as SCD and MCI are risk factors for AD, the detection of these conditions at primary care can contribute to early interventions, thus changing the outcome of clinical conditions related to memory loss.

Despite this clinical relevance, there are few studies of SCD in primary health care,${ }^{15}$ and most of them were conducted in populations from high-income countries, with high educational level. ${ }^{16}$ There is scarce data about cognitive impairment and memory complaints in low- and middle-income countries, ${ }^{10,16-19}$ especially in primary health care. As a matter of fact, the number of patients with dementia is globally increasing, especially in low and middle-income regions, such as Latin America, ${ }^{20}$ making it crucial to provide data about SCD and memory complaints in these populations.
The objective of this study was to characterize individuals with memory complaints in a mid-sized city in Minas Gerais State, Brazil, through a comprehensive clinical, cognitive and functional assessment. We also aimed to compare SCD individuals with MCI and dementia patients in terms of clinical and cognitive variables.

\section{METHODS}

This was an observational, cross-sectional study. Data collection was carried out from March to September 2016, at the Lagoa Grande Basic Health Unit in Patos de Minas. Patos de Minas is located in Minas Gerais (Southeast region, Brazil), with a population of 152,488 inhabitants. The Human Development Index (HDI, 2020) of the municipality of Patos de Minas is 0.765, which is slightly higher than that of Brazil (0.755, world rank 75th). Patos de Minas' gross domestic product (GDP-2019) per capita is about US\$5,182, which is lower than Brazil's index in 2019 (US\$ 6,155).

This study was proposed for individuals over 50 years of age who were consecutively seen at a general practice visit. Importantly, we did not include participants with previously established diagnosis of dementia. Figure 1 shows the flowchart of the study.

Subjects who spontaneously presented with memory complaints (as the main reason for the consultation, hereafter referred to as "spontaneous memory complaints") were submitted to neuropsychological and laboratory investigation. In turn, subjects who had no spontaneous complaint of memory deficits were asked about the functioning of memory with an open question ("How is your memory?"). Those who answered with memory complaints completed the Memory Complaint Questionnaire (MAC-Q), ${ }^{16}$ and those who scored 25 points or more on the MAC-Q were referred for neuropsychological and laboratory investigation. Individuals with no spontaneous memory complaints but who scored 25 or more on the MAC-Q are hereafter referred to as subjects with "inquired memory complaints".

Participants underwent a semi-structured questionnaire, describing sociodemographic and medical variables (comorbidities, use of medications, alcohol use, smoking, physical activity). Next, the Brief Cognitive Battery ${ }^{21}$ was applied, which includes the Mini-Mental State Examination (MMSE) ${ }^{22}$, the Figure Memory Test (FMT, a Visual Episodic Memory Test), ${ }^{18}$ the Clock Drawing Test ${ }^{23}$ and Verbal Fluency (Animal Category). ${ }^{24}$ Participants were also submitted to the Neuropsychiatric Inventory (NPI) ${ }^{25}$ and Functional Activity Questionnaire $(\text { FAQ })^{26}$ (Figure 1). All participants were submitted to laboratory tests to investigate cognitive decline, according to current recommendations. ${ }^{27}$ 
Based on clinical and neuropsychological data, subjects were classified into three clinical categories: 1 ) SCD (MAC-Q $\geq 25$, with no change in neuropsychological tests and no functional decline, FAQ $\leq 5)$; 2) MCI, with abnormal score in one of the cognitive tests (abnormal MMSE, FMT-Recall 5', $<7$, abnormal Verbal Fluency or Clock Drawing Test, $<4$ ), and preserved functional capacity, $\mathrm{FAQ} \leq 5$; and 3) dementia, with abnormal cognitive scores and functional impairment - FAQ >5). The normal cut-off scores for the MMSE ${ }^{22,24}$ and for Verbal Fluency were extracted from normative data for the Brazilian population, considering the educational level as follows: MMSE: ${ }^{22} 20$ - illiterate; $25-1$ to 4 years of schooling; $26-5$ to 8 years of schooling; $28-9$ to 11 years of schooling and 29 - more than 11 years of schooling;
Verbal Fluency Test - Animals: ${ }^{24} 11$ for illiterate, 13 for 1 to 4 years of study and 14 for more than 5 years of study.

Patients of the $\mathrm{MCI}$ and dementia groups were referred to brain computerized tomography (CT), without contrast, to investigate structural brain lesions. We did not include patients with structural brain lesions (e.g., brain tumor, subdural hematoma).

The study was approved by the Local Ethics Committee of the University Center of Patos de Minas (No. 1.733.241). All participants or their relatives, when necessary, signed an informed consent form after clarification.

\section{Statistical analyses}

All statistical analyses were performed using Statistical Package for the Social Sciences (SPSS) 22.0 (SPSS Inc.,

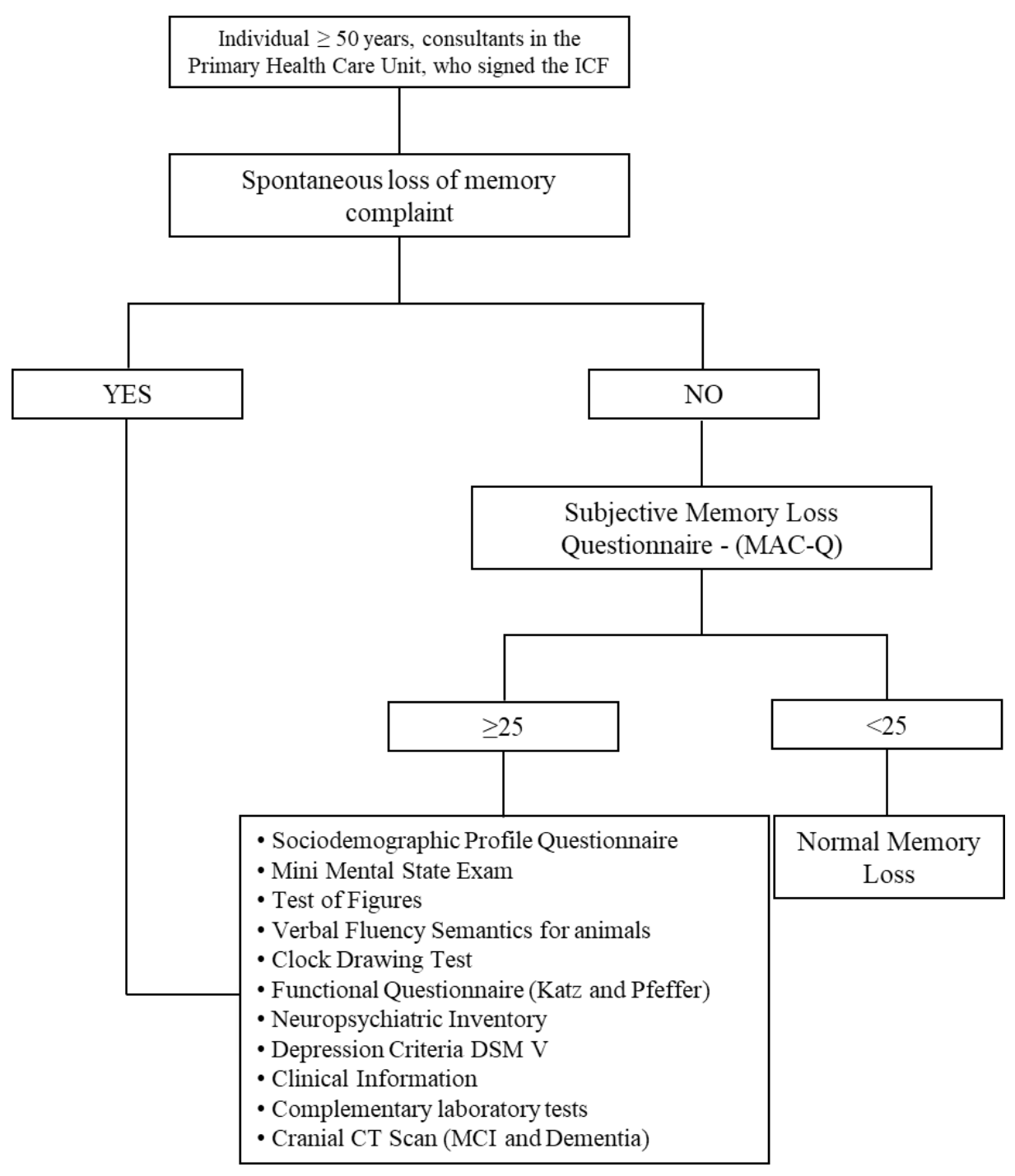

Figure 1. Study design. 
Chicago, IL). Qualitative variables were described according to frequencies and percentages. The normality of the quantitative variables was verified with the Shapiro-Wilk test, after visual inspection of the histograms. The chi-square test was used for comparing frequencies between groups. Comparisons between continuous variables with normal distribution were analyzed by ANOVA, followed by the Tukey test. For non-normal distribution continuous variables, the Mann-Whitney test (for two independent groups) or the Kruskal-Wallis test (for comparison of multiple groups, followed by the Dunn post-test, when appropriate) was used. We adopted Bonferroni's correction for multiple comparisons and the level of significance $(\alpha)$ was set at 0.004 .

\section{RESULTS}

\section{Descriptive analysis (total population)}

During the study period, 432 individuals were referred for medical consultation at the Lagoa Grande Basic Health Unit, with 275 of them considered "initial sample" with age equal to or greater than 50 years. Among these, 167 subjects did not present with memory complaints (either spontaneous or inquired), while 108
(39\% of the initial sample) had either spontaneous or inquired memory complaints. Seventeen subjects were excluded for the following reasons: (refused to undergo cognitive tests) $(n=8)$, brain tumor $(n=1)$, changed area covered by the health unit $(\mathrm{n}=3)$ and score $<25$ on MAC-Q ( $n=5)$. The final sample of the study consisted of 91 participants (Figure 2), being 13 (14.3\%) with spontaneous memory complaints and $78(85.7 \%)$ with inquired memory complaints.

Table 1 presents the demographic data of the sample. Women $(74.7 \%)$, with mean age of 67.6 years $( \pm 9.8)$, composed most of the study population. Most individuals had low educational level (4-8 years of schooling - $\mathrm{n}=47,51.7 \%$ ).

Table 2 shows comorbidities and medications in use for the study population. Systemic arterial hypertension was present in 69\%; diabetes, dyslipidemia and hypothyroidism were found in $36.3,25.3$ and $22 \%$, respectively. Regarding medications, $33 \%$ of participants used antidepressants or anxiolytics (mainly selective serotonin reuptake inhibitors) and $23 \%$ used a proton pump inhibitor. Laboratory analyses found that $26.4 \%$ had low levels of vitamin B12, and $16.5 \%$ had thyroid-stimulating hormone (TSH) levels above normal. None of the individuals tested positive for



BHU: Basic Health Unit.

Figure 2. Sample flowchart 
human immunodeficiency virus (HIV) or syphilis. Most patients (MCI and dementia) did not show abnormalities on CT scan. Leukoaraiosis was found in $7.6 \%$ of $\mathrm{MCI}$ or patients with dementia, being more frequent in the dementia group.
Comparison of groups: spontaneous vs inquired memory complaints

Among subjects with memory complaints ( $\mathrm{n}=91), 13$ (14.3\%) had spontaneous memory complaints and 78 (85.7\%) had inquired memory complaints. Individuals

Table 1. Demographic data $(n, \%)$ for the study population, according to clinical group.

\begin{tabular}{|c|c|c|c|c|c|}
\hline & & $\begin{array}{c}\text { SCD } \\
(n=15)\end{array}$ & $\begin{array}{c}\text { MCI } \\
(n=45)\end{array}$ & $\begin{array}{l}\text { Dementia } \\
(n=31)\end{array}$ & $\begin{array}{l}\text { Total } \\
(n=91)\end{array}$ \\
\hline \multirow{2}{*}{$\operatorname{Sex}^{*}$} & Female & 8 (53.3\%) & 35 (77.8\%) & 25 (80.6\%) & $68(74.7 \%)$ \\
\hline & Male & 7 (46.7\%) & $10(22.2 \%)$ & $6(19.4 \%)$ & $23(25.3 \%)$ \\
\hline $\begin{array}{l}\text { Age }(\text { mean } \pm \text { standard } \\
\text { deviation) })^{\S}\end{array}$ & & $64.9 \pm 9^{a}$ & $66.4 \pm 8.9$ & $70.6 \pm 10.8$ & $67.6 \pm 9.7$ \\
\hline \multirow{5}{*}{ Schooling (years) ${ }^{*}$} & Illiterates & $1(6.7 \%)$ & $2(4.4 \%)$ & $4(12.9 \%)$ & $7(7.7 \%)$ \\
\hline & 1 to 3 & $5(33.2 \%)$ & $11(24.5 \%)$ & 8 (25.8\%) & $24(26.4 \%)$ \\
\hline & 4 to 8 & $7(46.7 \%)$ & $24(53.3 \%)$ & $16(51.6 \%)$ & 47 (51.6\%) \\
\hline & 9 to 11 & $1(6.7 \%)$ & $3(6.7 \%)$ & $1(3.2 \%)$ & $5(5.5 \%)$ \\
\hline & $>11$ & $1(6.7 \%)$ & $5(11.1 \%)$ & $2(6.5 \%)$ & $8(8.8 \%)$ \\
\hline \multirow{4}{*}{$\begin{array}{l}\text { Family income } \\
\text { (in Brazilian minimum wage) }{ }^{*}\end{array}$} & 1 to 2 & $11(3.3 \%)$ & 27 (60.0\%) & $16(51.6 \%)$ & $54(59.3 \%)$ \\
\hline & 3 to 5 & $4(26.7 \%)$ & $16(35.6 \%)$ & $14(45.2 \%)$ & 34 (37.4\%) \\
\hline & 6 to 10 & $0(0.0 \%)$ & $2(4.4 \%)$ & $1(3.2 \%)$ & $3(3.3 \%)$ \\
\hline & $>10$ & $0(0.0 \%)$ & $0(0.0 \%)$ & $0(0.0 \%)$ & $0(0.0 \%)$ \\
\hline \multirow{4}{*}{ Civil status ${ }^{*}$} & Unmarried & $3(20.0 \%)$ & $2(4.4 \%)$ & $3(9.7 \%)$ & $8(8.8 \%)$ \\
\hline & Married & $10(66.7 \%)$ & $24(53.3 \%)$ & $17(54.8 \%)$ & $51(56.0 \%)$ \\
\hline & Widow & $2(13.3 \%)$ & $12(26.7 \%)$ & $8(25.8 \%)$ & $22(24.2 \%)$ \\
\hline & Divorced & $0(0.0 \%)$ & $7(15.6 \%)$ & $3(9.7 \%)$ & $10(11.0 \%)$ \\
\hline
\end{tabular}

MCl: mild cognitive impairment; SCD: subjective cognitive decline. The $\mathrm{p}$-values refer to the significance level of the comparison between the 3 groups. ${ }^{*}$ The frequency of qualitative variables


Wallis test. ${ }^{a} \mathrm{p}<0.05$ (subjective complaint vs dementia).

Table 2. Clinical data (medications and comorbidities) for the study population, according to clinical group (n, \%).

\begin{tabular}{lccc}
\hline & $\begin{array}{c}\text { SCD } \\
(\mathbf{n = 1 5})\end{array}$ & $\begin{array}{c}\text { MCI } \\
(\mathbf{n = 4 5 )}\end{array}$ & $\begin{array}{c}\text { Dementia } \\
(\mathbf{n = 3 1 )}\end{array}$ \\
\hline Medications & & $9(20 \%)$ & $10(32.2 \%)$ \\
\hline Proton pump inhibitor & $2(13.3 \%)$ & $12(26.7 \%)$ & $14(45.2 \%)$ \\
\hline Antidepressant & $4(26.7 \%)$ & $1(2.2 \%)$ & $1(3.2 \%)$ \\
\hline Typical antipsychotic & $0(0 \%)$ & $0(0 \%)$ & $1(3.2 \%)$ \\
\hline Atypical antipsychotic & $0(0 \%)$ & $6(13.3 \%)^{\mathrm{a}}$ & $13(41.9 \%)$ \\
\hline Benzodiazepine & $3(20.0 \%)$ & & $2(6.4 \%)$ \\
\hline p<0.015 & & & $3(17.7 \%)$ \\
\hline Alchool use & $2(13.3 \%)$ & $5(11.1 \%)$ & $24(77.4 \%)$ \\
\hline Smoking & $2(13.3 \%)$ & $28(62.2 \%)$ & $11(35.5 \%)$ \\
\hline Hypertension & $11(73.3 \%)$ & $17(37.8 \%)$ & $5(16.1 \%)$ \\
\hline Diabetes & $5(33.3 \%)$ & $12(26.7 \%)$ & $7(22.6 \%)$ \\
\hline Dyslipidemia & $6(40.0 \%)$ & $9(20.0 \%)$ & \\
\hline Hypothyroidism & $4(26.7 \%)$ & & \\
\hline
\end{tabular}

SCD: subjective cognitive decline; MCl: mild cognitive impairment; ${ }^{a} p<0.05$ (dementia vs MCI). 
from these groups did not differ in age, sex distribution, schooling and family income (Supplementary Table). The two groups did not differ in the frequency of clinical diseases (hypertension, diabetes, dyslipidemia, and hypothyroidism).

Regarding the cognitive diagnoses, SCD, $\mathrm{MCI}$ and dementia were identified in one $(7.7 \%)$, five $(38.5 \%)$ and seven (53.4\%) subjects with spontaneous memory complaints, respectively. In the group with inquired memory complaints, 12 (15.4\%), 42 (53.4\%) and 24 (30.8\%) had SCD, MCI and dementia, respectively.

Table 3 presents the cognitive data of all participants. Compared to subjects with inquired memory complaints, those with spontaneous memory complaints had lower scores on the MMSE, but without statistical significance $(\mathrm{p}=0.015)$. These groups did not differ in 5'Recall (FMT), Animal Fluency and Clock Drawing Test.

Table 3. Neuropsychological data (mean \pm standard deviation) for clinical groups according to complaint type.

\begin{tabular}{lcc}
\hline & $\begin{array}{c}\text { Spontaneous } \\
\text { complaint } \\
(\mathbf{n}=\mathbf{1 3}, \mathbf{1 4 . 3} \%)\end{array}$ & $\begin{array}{c}\text { Inquired } \\
\text { complaint } \\
(\mathbf{n}=\mathbf{7 8 , 8 5 . 7 \% )}\end{array}$ \\
\hline $\begin{array}{l}\text { MAC-Q } \\
\mathbf{p}<0.05\end{array}$ & $31.1 \pm 3.7$ & $29.3 \pm 3.0^{\mathrm{b}}$ \\
\hline $\begin{array}{l}\text { MMSE } \\
\mathrm{p}<0.01\end{array}$ & $19.8 \pm 3.8$ & $22.8 \pm 4.5^{\mathrm{a}}$ \\
\hline $\begin{array}{l}\text { Figure Memory Test (Recall 5') } \\
\mathrm{p}<0.05\end{array}$ & $5.2 \pm 3.2$ & $7.0 \pm 2.2^{\mathrm{b}}$ \\
\hline Verbal Fluency (Animals) & $8.3 \pm 2.8$ & $9.8 \pm 3.5$ \\
\hline Clock Drawing Test & $3.5 \pm 1.7$ & $3.2 \pm 1.9$ \\
\hline FAQ & $3.0 \pm 2.7$ & $2.4 \pm 2.6$ \\
\hline
\end{tabular}

FAQ: Functional Activity Questionnaire; MAC-Q: Memory Complaint Questionnaire; MCl: mild cognitive impairment; MMSE: Mini-Mental State Examination; SCD: subjective cognitive decline. The comparison between groups was performed using the Mann-Whitney test; ${ }^{a} p<0.01$ (spontaneous vs surveyed); ${ }^{p} p<0.05$ (spontaneous vs respondent).

\section{Comparison of groups: subjective cognitive decline, mild cognitive impairment and dementia}

According to clinical criteria, participants $(\mathrm{n}=91)$ were clinically categorized as follows: 15 (16.5\%) with SCD, 45 (49.4\%) with MCI and 31 (34.1\%) with dementia.

These three groups did not differ in age, sex distribution, schooling and family income. There was no statistically significant difference in the frequency of comorbidities (hypertension, diabetes, dyslipidemia, and hypothyroidism) between groups. The frequency of use of antidepressants, antipsychotics and proton pump inhibitors did not differ across groups, but there was a trend $(\mathrm{p}<0.015)$ for a higher frequency of benzodiazepine use in the dementia group, when compared to the MCI group. Participants with regular physical activity were $8.3,31.2$ and $16.1 \%$ in the SCD, MCI and dementia groups, respectively.

Table 4 presents cognitive tests and scales for the clinical groups (SCD, MCI and dementia). There was a statistically significant difference in MMSE between groups, with higher scores in the SCD group, and lower in the dementia group, with $\mathrm{MCI}$ showing intermediate scores $(\mathrm{SCD}<\mathrm{MCI}<$ dementia). Similarly, individuals with dementia performed worse than MCI $(\mathrm{p}<0.002)$ and SCI $(\mathrm{p}<0.001)$ individuals in the 5'Recall (FMT). Compared to SCD and MCI, patients with dementia also underperformed on Animal Fluency and on the Clock Drawing Test. Individuals with SCD and MCI had similar performances on all cognitive tests, except for MMSE ( $\mathrm{p}<0.001)$, with lower scores in the MCI group.

The scores on the NPI across the groups are shown in Table 5. The groups did not differ in the following scores: disinhibition, dysphoria, anxiety, irritability, aberrant motor behavior, euphoria and night-time behavioral disturbances. Dementia group had higher scores than SCD on the NPI total score $(\mathrm{p}<0.002)$. Compared to MCI group, patients with

Table 4. Neuropsychological data (mean \pm standard deviation) for the study population, according to clinical group.

\begin{tabular}{lccc} 
& $\begin{array}{c}\text { SCD } \\
(\mathbf{n = 1 5 )}\end{array}$ & $\begin{array}{c}\text { MCI } \\
(\mathbf{n = 4 5 )}\end{array}$ & $\begin{array}{c}\text { Dementia } \\
(\mathbf{n}=\mathbf{3 1})\end{array}$ \\
\hline MAC-Q & $29.3 \pm 2.9$ & $29.0 \pm 2.8$ & $30.4 \pm 3.7$ \\
\hline $\begin{array}{l}\text { MMSE } \\
\mathrm{p}<0.001\end{array}$ & $26.7 \pm 1.8^{\mathrm{a}, \mathrm{b}}$ & $23.4 \pm 3.4^{\mathrm{a}}$ & $18.7 \pm 4.3$ \\
\hline $\begin{array}{l}\text { Figure Memory Test (Recall 5') } \\
\mathrm{p}<0.001\end{array}$ & $8.1 \pm 1.1^{\mathrm{a}}$ & $7.3 \pm 2.0^{\mathrm{a}}$ & $5.3 \pm 2.7$ \\
\hline $\begin{array}{l}\text { Verbal Fluency (Animals) } \\
\mathrm{p}<0.001\end{array}$ & $12.4 \pm 1.8^{\mathrm{a}}$ & $9.9 \pm 3.5$ & $7.7 \pm 2.9$ \\
\hline Clock Drawing Test & $3.9 \pm 1.3$ & $3.6 \pm 1.6$ & $2.3 \pm 2.0$ \\
\hline FAQ & $1.0 \pm 1.3$ & $1.0 \pm 1.0$ & $12.5 \pm 7.9$ \\
\hline
\end{tabular}

FAQ: Functional Activity Questionnaire; MAC-Q: Memory Complaint Questionnaire; MCl: mild cognitive impairment; MMSE: Mini-Mental State Examination; SCD: subjective cognitive decline; ${ }^{a}$ significant difference vs dementia group ( $p<0.004$; Mann-Whitney test); " significant difference vs MCI group ( $p<0.004$; Mann-Whitney test). 
dementia scored higher on apathy $(\mathrm{p}<0.001)$, agitation $(\mathrm{p}<0.003)$, appetite disorders $(\mathrm{p}<0.004)$ and on the NPI total score $(\mathrm{p}<0.001)$. The groups SCD and MCI did not differ in any of NPI scores.

\section{DISCUSSION}

This study aimed to characterize complaints of memory loss in adults in primary health care in a middle-income country (Brazil). We found that clinical diseases, such as systemic arterial hypertension and hypothyroidism, were frequently observed in patients with memory complaints. We also identified notable frequencies of underdiagnosis of dementia and of treatable causes of cognitive decline among individuals with memory complaints. Finally, as an original contribution, we provide clinical characterization of subjects with SCD at primary health care in a middle-income country.

In line with previous studies, ${ }^{1,10,11,12,28}$ most of our sample was composed of women. The reasons for this are unclear, but both medical and sociological issues may account for this ${ }^{28}$. Women look for medical care more frequently than men, ${ }^{28}$ and it is possible that the memory loss in men is underdiagnosed.

There is scarce data about cognitive impairment and memory complaints in low- and middle-income countries, especially in primary health care. Data from India and China found respectively 10.8 and $17 \%$ of patients with cognitive impairment in primary health care surveys. ${ }^{17,29}$ The prevalence of memory complaints and cognitive impairment is heterogeneous across studies, ranging from 8 to $50 \% .^{6-8}$ Methodological issues, such as the target population (primary care, secondary outpatient clinics or referral centers) and differences on cognitive screening tests may explain the variability of the results across studies. Interestingly, the frequency of memory complaints in our sample is similar to that observed in study conducted at a high-income country. ${ }^{30}$ Waldorff and colleagues ${ }^{30}$ reported that $24 \%$ of Danish patients seen at primary health care had memory complaints. However, that study selected patients at least 65 years-old, while our study included individuals over 50 years of age. It is possible that we would find higher frequencies of memory complaints if we had included only patients over 65 .

A previous study with elderly Brazilians community-living setting found that memory complaints were associated with low schooling and depressive symptoms but did not correlate with cognitive performance. ${ }^{10} \mathrm{An}$ other Brazilian study found that the score on the Memory Complaints Scale correlated with the MMSE and with measures of visual-spatial abilities and orientation. ${ }^{18}$

This study investigated both inquired and spontaneous memory complaints. We found that inquired memory complaints $(\mathrm{n}=78 ; 85.7 \%)$ were more frequent than spontaneous memory complaints $(n=13 ; 14.3 \%)$, in line with Burmester et al., ${ }^{31}$ who reported that the frequency of spontaneous memory complaints was lower than when actively investigated with a structured questionnaire, in a large survey with 421 individuals. Again, these results raise the problem of underdiagnosis of cognitive decline in primary care.

Table 5. Scores (mean \pm standard deviation) on the Neuropsychiatric Inventory, according to clinical group.

\begin{tabular}{|c|c|c|c|}
\hline Neuropsychiatric Inventory & $\begin{array}{c}\text { SCD } \\
(n=15)\end{array}$ & $\begin{array}{c}\text { MCI } \\
(n=45)\end{array}$ & $\begin{array}{c}\text { Dementia } \\
(n=31)\end{array}$ \\
\hline Hallucinations & $0.0 \pm 0.0$ & $0.0 \pm 0.0$ & $0.4 \pm 1.7$ \\
\hline Delusions & $0.0 \pm 0.0$ & $0.0 \pm 0.0$ & $0.4 \pm 1.5$ \\
\hline Apathy & $0.2 \pm 0.6$ & $1.2 \pm 2.2^{\mathrm{a}}$ & $4.3 \pm 4.7$ \\
\hline Dysphoria & $2.5 \pm 3.2$ & $2.5 \pm 3.55$ & $4.9 \pm 3.9$ \\
\hline Agitation/aggression & $0.1 \pm 0.3$ & $0.6 \pm 2.1^{\mathrm{a}}$ & $3.2 \pm 4.3$ \\
\hline Anxiety & $3.4 \pm 4.7$ & $2.8 \pm 3.6$ & $5.4 \pm 4.7$ \\
\hline Disinhibition & $0.1 \pm 0.3$ & $0.19 \pm 0.55$ & $0.4 \pm 1.2$ \\
\hline Irritability/lability & $1.4 \pm 2.7$ & $1.7 \pm 3.4$ & $3.3 \pm 4.6$ \\
\hline Aberrant motor activity & $0.0 \pm 0$ & $0.03 \pm 2.15$ & $0.6 \pm 2.0$ \\
\hline Euphoria & $0.0 \pm 0$ & $0.03 \pm 2.15$ & $0.3 \pm 1.5$ \\
\hline Appetite and eating abnormalities & $0.5 \pm 1.7$ & $0.85 \pm 2.3^{\mathrm{a}}$ & $3.7 \pm 4.8$ \\
\hline Night-time behavioral disturbances & $0.0 \pm 0$ & $0.6 \pm 2.26$ & $1.3 \pm 3.4$ \\
\hline Total score & $11.1 \pm 16.5^{\mathrm{a}}$ & $10.2 \pm 13.2^{\mathrm{a}}$ & $28.4 \pm 21.6$ \\
\hline
\end{tabular}

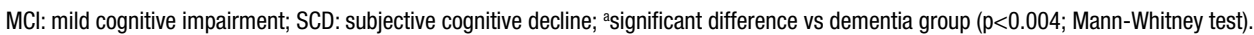


Interestingly, subjects with spontaneous memory complaints had similar performance than those with inquired memory complaints on the cognitive tests. However, the frequency of dementia tended to be higher among participants with spontaneous memory complaints (53.4\%) than in those with inquired memory complaints (30.8\%). These results suggest that individuals with spontaneous memory complaints should be carefully screened for cognitive decline and dementia.

Previous diagnosis of dementia was an exclusion criterion, but 31 patients (34.1\%) with memory complaints (seven with spontaneous memory complaints and 24 with inquired complaints) fulfilled criteria for dementia. All dementia patients had mild to moderate functional impairment, and none had severe dementia. These findings are in agreement with a recent meta-analysis showing that the underdiagnosis of dementia is high, with middle-income countries showing higher rates (above $90 \%$ ) than in high-income countries (around 60\%). ${ }^{32}$ These results reinforce the urgent need for dementia screening at primary care.

We identified 15 out 91 (16.5\%) individuals with SCD, i.e., patients who had memory complaints but with no objective deficit on cognitive assessment. ${ }^{33}$ To the best of our knowledge, this is one of the first reports of frequency of SCD in a middle-income country. ${ }^{18}$ Considering that $S C D$ is associated with increased risk for developing $\mathrm{MCI}$ and $\mathrm{AD},{ }^{14}$ a clinical follow-up of these individuals is warranted.

In agreement with previous studies, non-communicable chronic diseases such as systemic arterial hypertension, diabetes mellitus and dyslipidemia were frequently observed in our sample. ${ }^{34-36}$

Interestingly, there was no difference in frequencies of these comorbidities across groups of SCD, MCI and dementia. The interactions between these conditions and cognitive performance are a matter of debate. A Brazilian study did not find a significant difference in verbal fluency between healthy controls and patients with hypertension and/or diabetes, ${ }^{37}$ but other studies found an association between poor cognitive performance and cardiometabolic diseases such as hypertension, diabetes and obesity. ${ }^{37,38}$ Importantly, schooling may modulate the impact of these diseases in cognitive performance, as education is associated with adherence to preventive measures. ${ }^{39}$

Of note, we found substantial percentages of patients with potential reversible causes of cognitive decline. For instance, $26.4 \%$ of participants with memory complaints had low levels of vitamin B12, and 16.5\% had abnormal TSH levels. These data reinforce the need for comprehensive screening for non-degenerative causes of cognitive deficit at primary care settings.
Patients with dementia had higher scores on the NPI than SCD and MCI patients. The use of benzodiazepines tended to be more frequent among patients with dementia thus suggesting that these medications were prescribed for treating neuropsychiatric symptoms associated with dementia. There is evidence that long-term use of benzodiazepines is associated with an increased risk of dementia, ${ }^{40-42}$ although this association may be considered causal. ${ }^{42,43}$ Considering the cross-sectional design of our study, we cannot establish a causal relation between benzodiazepine use and dementia. On the other hand, these medications are associated with increased risk of falls ${ }^{40}$ and impairment in executive abilities ${ }^{41}$ in patients with dementia. Our data support the need for a detailed inventory of medications in use in patients with memory complaints, to avoid possible negative effects, especially in patients with established dementia.

This study has some limitations. Besides the small sample size, we did not include a control group, without memory complaints, which would be of value for comparative purposes. Considering that we employed a self-scale for screening of memory complaints, it is possible that subjects with anosognosia were not retained in the study. Moreover, the value of the MAC-Q as a screening tool is limited by the interference of the affective status, ${ }^{44}$ but the MAC-Q has been successfully used in the Brazilian population. ${ }^{10}$ The diagnosis was established on clinical grounds, and participants did not undergo formal neuropsychological examination and did not pass advanced investigation with brain magnetic resonance imaging and biological markers of AD. Therefore, we cannot establish the etiology for cognitive decline and dementia in our group. Finally, we adopted strict statistical correction for multiple comparisons, to avoid spurious results. It is possible that we would find more differences for clinical and cognitive variables between groups using a less strict level of significance (e.g., $\mathrm{p}<0.05$ ).

Despite these limitations, this study provides relevant clinical information to general practitioners working at the primary health care level, as well as for public health programs. The early diagnosis of cognitive decline provides the best opportunities for care planning and medical assistance for patients and caregivers. In this context, physicians and the primary care team play a key role in the early recognition of cognitive impairment in their patients. ${ }^{45}$ We detected substantial percentages of non-diagnosed $\mathrm{MCI}$ and dementia among individuals with memory complaints, and we also found that potentially reversible causes of cognitive impairment, such as hypovitaminosis B12 and hypothyroidism, are frequent at primary care. We also identified that the 
diagnosis of dementia was very frequent among subjects with spontaneous memory complaints. Taken together, these results reinforce the central role of primary care assistance in the diagnosis and medical care of individuals with memory complaints. Finally, we suggest that physicians in primary health care be trained to diagnose $\mathrm{MCI}$ and dementia and to perform longitudinal monitoring of individuals with SCD as well.
Authors' contributions. MLP: conceptualization, methodology, data curation, formal analysis, visualization, writing - original draft. THFV, AARO, SBC, SOF: investigation, data curation. AFBCG: resources, data curation. MTB, LFJRM, PC: writing - review \& amp; editing. LCS: supervision, conceptualization, methodology, data curation, formal analysis, writing - review \& amp; editing.

\section{REFERENCES}

1. Oliveira GM, Cachioni M, Falcão D, Batistoni S, Lopes A, Guimarães V, et al. Relationships between episodic memory performance prediction and sociodemographic variables among healthy older adults. Dement Neuropsychol. 2015;9(1):58-63. https://doi.org/10.1590/S198057642015 DN91000008

2. Salthouse TA. Influence of age on practice effects in longitudinal neurocognitive change. Neuropsychology. 2010;24(5):563-72. https://doi. org/10.1037/a0019026

3. Lima-Silva TB, Yassuda MS. The relationship between memory complaints and age in normal aging. Dement Neuropsychol. 2009;3(2):94-100. https://doi.org/10.1590/S1980-57642009DN30200005

4. Bottino CM, Pádua AC, Smid J, Areza-Fegyveres R, Novaretti T, Bahia VS. Differential diagnosis between dementia and psychiatric disorders: diagnostic criteria and further tests. Recommendations of the Scientific Department of Cognitive Neurology and Aging of the Brazilian Academy of Neurology. Dement Neuropsicol. 2011;5(4):288-96. http://dx.doi. org/10.1590/S1980-57642011DN05040006

5. Razvi S, Weaver JU, Pearce SH. Subclinical thyroid disorders: significance and clinical impact. J Clin Pathol. 2010;63(5):379-86. https://doi. org/10.1136/jcp.2008.057414

6. Eichler T, Thyrian JR, Hertel J, Wucherer D, Michalowsky B, Reiner K, et al. Subjective memory impairment: No suitable criteria for case-finding of dementia in primary care. Alzheimers Dement (Amst). 2015;1(2):179-86. https://doi.org/10.1016/j.dadm.2015.02.004

7. Papachristou E, Ramsay SE, Papacosta O, Lennon LT, lliffe S, Whincup $\mathrm{PH}$, et al. The Test Your Memory cognitive screening tool: sociodemographic and cardiometabolic risk correlates in a population-based study of older British men. Int J Geriatr Psychiatry. 2016;31(6):666-75. https:// doi.org/10.1002/gps.4377

8. Bernardes FR, Machado CK, Souza MC, Machado MJ, Belaunde AM. Subjective memory complaints and their relation with verbal fluency in active older people. Codas. 2017;29(3):e20160109. https://doi. org/10.1590/2317-1782/20172016109

9. Paulo DL, Yassuda MS. Memory complaints of the elderly and their relationship with education, cognitive performance and symptoms of depression and anxiety. Rev Psiquiatr Clin. 2010;37(1):23-6. https://doi. org/10.1590/S0101-60832010000100005

10. Silva LS, Silva TB, Falcão DV, Batistoni SS, Lope A, Cachioni M, et al. Relations between memory complaints, depressive symptoms and cognitive performance among community dwelling elderly. Rev Psiquiatr Clin. 2014;41(3):67-71. https://doi.org/10.1590/0101-60830000000013

11. Jonker C, Geerlings MI, Schmand B. As queixas de memória são preditivas de demência? Uma revisão de estudos clínicos e populacionais. Int J Geriatr Psychiatry. 2000;15(11):983-91. https://doi.org/10.1002/ 1099-1166(200011)15:11<983::AID-GPS238>3.0.CO;2-5

12. Coley N, Ousset PJ, Andrieu S, Matheix Fortunet H, Vellas B. Memory complaints to the general practitioner: data from the GuidAge study. J Nutr Health Aging. 2008;12(1):66S-72S. https://doi.org/10.1007/BF02982590

13. Jessen F, Amariglio RE, Buckley RF, van der Flier WM, Han Y, Molinuevo JL, et al. The characterisation of subjective cognitive decline. Lancet Neurol. 2020;19(3):271-8. https://doi.org/10.1016/S1474-4422(19)30368-0

14. Miyagawa T, Iwata A. Subjective memory complaints (SMC). Nihon Rinsho. 2016;74(3):451-4.

15. Roehr S, Pabst A, Luck T, Riedel-Heller SG. A incidência de demência está diminuindo em países de alta renda? Uma revisão sistemática e meta-análise. Clin Epidemiol. 2018;10:1233-47. https://doi.org/10.2147/ CLEP.S163649
16. Mattos P, Lino V, Rizo L, Alfano A, Araújo C, Raggio R. Memory complaints and test performance in healthy elderly persons. Arq Neuro-Psiquiatr. 2003;61(4):920-4. https://doi.org/10.1590/s0004-282x2003000600006

17. Krishnamoorthy Y, Sarveswaran G, Sakthivel M, Rehman T, Majella, S. Ganesh MG. Screening for mild cognitive impairment among noncommunicable disease patients attending a rural primary health center in Puducherry, South India. J Nat Sc Biol Med. 2019;10(1):77-81. https:// doi.org/10.4103/jnsbm.JNSBM_90_18

18. Dalpubel D, Rossi PG, de Almeida ML, Ribeiro EB, Araújo R, de Andrade $L P$, et al. Subjective memory complaint and its relationship with cognitive changes and physical vulnerability of community-dwelling older adults. Dement Neuropsychol. 2019;13(3):343-9. https://doi.org/10.1590/ 1980-57642018dn13-030012

19. Zlatar ZZ, Muniz MC, Espinoza SG, Gratianne R, Gollan TH, Galasko D, et al. Subjective cognitive decline, objective cognition, and depression in older hispanics screened for memory impairment. J Alzheimers Dis. 2018;63(3):949-56. https://doi.org/10.3233/JAD-170865

20. GBD 2016 Dementia Collaborators. Global, regional, and national burden of Alzheimer's disease and other dementias, 1990-2016: a systematic analysis for the Global Burden of Disease Study 2016. Lancet Neurol. 2019;18(1):88-106. https://doi.org/10.1016/S1474-4422(18)30403-4

21. Nitrini R, Caramelli P, Herrera Júnior E, Porto CS, Charchat-Fichman $H$, Carthery MT, et al. Desempenho de idosos analfabetos e alfabetizados não-discriminados em dois testes de memória de longa duração. J Int Neuropsychol Soc. 2004;10(4):634-8. https://doi.org/10.1017/ S1355617704104062

22. Brucki SM, Nitrini R, Caramelli P, Bertolucci $P H$, Okamoto $\Vdash$. Sugestões para o uso do mini-exame do estado mental no Brasil [Suggestions for utilization of the mini-mental state examination in Brazil]. Arq Neuro-Psiquiatr. 2003;61(3B):777-81. https://doi.org/10.1590/s0004$282 \times 2003000500014$

23. Shulman KI. Desenho do relógio: é o teste de rastreio cognitivo ideal? Int J Geriatr Psychiatry. 2000;15(6):548-61. https://doi.org/10.1002/ 1099-1166(200006)15:6<548::aid-gps242>3.0.co;2-u

24. Yassuda MS, da Silva HS, Lima-Silva TB, Cachioni M, Falcão DVDS, Lopes A, et al. Dados normativos da Bateria Breve de Triagem Cognitiva estratificada por idade e escolaridade. Dement Neuropsychol. 2017;11(1):48-53. https://doi.org/10.1590/1980-57642016dn11-010008

25. Camozzato AL, Godinho C, Kochhann R, Massochini G, Chaves M. Validade da versão brasileira do Neuropsychiatric Inventory Questionnaire (NPI-Q). Arq Neuro-Psiquiatr. 2015;73(1):41-5. https://doi.org/10.1590/ 0004-282X20140177

26. Pfeffer RI, Kurosaki TT, Harrah CH Jr, Chance JM, Filos S. Measurement of functional activities in older adults in the community. J Gerontol. 1982;37(3):323-9. https://doi.org/10.1093/geronj/37.3.323

27. Nitrini R, Caramelli P, Bottino CM, Damasceno BP, Brucki SM, Anghinah R; Academia Brasileira de Neurologia. Diagnosis of Alzheimer's disease in Brazil: diagnostic criteria and auxiliary tests. Recommendations of the Scientific Department of Cognitive Neurology and Aging of the Brazilian Academy of Neurology. Arq Neuro-Psiquiatr. 2005;63(3A):713-9. https:// doi.org/10.1590/s0004-282×2005000400033

28. Lavery LL, Lu SY, Chang CC, Saxton J, Ganguli M. Avaliação cognitiva de pacientes idosos da atenção primária com e sem queixas de memória. J Gen Intern Med. 2007;22(7):949-54. https://doi.org/10.1007/s11606007-0198-0

29. Zhang D, Sit RW, Wong C, Zou D, Mercer SW, Johnston MC, Wong SY. Cohort profile: The prospective study on Chinese elderly with multimor- 
bidity in primary care in Hong Kong. BMJ Open. 2020;10(2):e027279. https://doi.org/10.1136/bmjopen-2018-027279

30. Waldorff FB, Siersma V Vogel A Waldemar G Subjective memory complaints in general practice predicts future dementia: a 4-year follow-up study. Int J Geriatr Psychiatry. 2012;27(11):1180-8. https://doi.org/10.1002/gps.3765

31. Burmester B, Leathem J, Merrick P. Assessing subjective memory complaints: a comparison of spontaneous reports and structured questionnaire methods. Int Psychogeriatr. 2015;27(1):61-77. https://doi.org/10.1017/ S1041610214001161

32. Lang L, Clifford A, Wei L, Zhang D, Leung D, Augustine G, et al. Prevalence and determinants of undetected dementia in the community: a systematic literature review and a meta-analysis. BMJ Open. 2017;7(2):e011146. https://doi.org/10.1136/bmjopen-2016-011146

33. Studart Neto A, Nitrini R. Declínio cognitivo subjetivo: a primeira manifestação clínica da doença de Alzheimer? Dement Neuropsychol. 2016;10(3):170-17. https://doi.org/10.1590/S1980-57642016DN1003002

34. Machado JC, Ribeiro RC, Cotta RMM, Leal PF. Cognitive decline of the elderly and its association with epidemiological factors in Viçosa, Minas Gerais. Minas Gerais. Rev Bras Geriatr Gerontol, 2011;14(1):109-21. https://doi.org/10.1590/S1809-98232011000100012

35. Soares LM, Cachioni M, Falcão DV, Batistoni SS, Lopes A, Neri AL, Yassuda MS. Determinants of cognitive performance among community dwelling older adults in an impoverished sub-district of São Paulo in Brazil. Arch Gerontol Geriatr. 2012;54(2):e187-92. https://doi.org/10.1016/j. archger.2011.11.014

36. Fougère B, Oustric $S$, Delrieu J, Chicoulaa B, Escourrou E, Rolland Y, et al. FAP group. Implementing assessment of cognitive function and frailty into primary care: data from frailty and Alzheimer disease prevention into Primary care (FAP) Study Pilot. J Am Med Dir Assoc. 2017;18(1):47-52. https://doi.org/10.1016/j.jamda.2016.08.003

37. Morelli NL, Cachioni M, Lopes A, Batistoni SS, Falcão DV, Nery $A L$, et al. Verbal fluency in elderly with and without hypertension and diabetes from the FIBRA study in Ermelino Matarazzo. De- ment Neuropsychol. 2017:11(4):413-8, https://doi.org/10.1590/ 1980-57642016dn11-040011

38. Muela HC, Costa-Hong VA, Yassuda MS, Machado MF, Nogueira $\mathrm{RC}$, Moraes NC, et al. Impact of hypertension severity on arterial stiffness, cerebral vasoreactivity, and cognitive performance. Dement Neuropsychol. 2017;11(4):389-97. https://doi.org/10.1590/ 1980-57642016dn11-040008

39. de Oliveira MF, Yassuda MS, Aprahamian I, Neri AL, Guariento ME. Hipertensão, diabetes e obesidade estão associados a baixo desempenho cognitivo em idosos residentes na comunidade: Dados do estudo FIBRA. Dement Neuropsychol. 2017;11(4):398-405. https://doi.org/10.1590/ 1980-57642016dn11-040009

40. Takada M, Fujimoto M, Hosomi K. Association between benzodiazepine use and dementia: data mining of different medical databases. Int J Med Sci. 2016;13(11):825-34. https://doi.org/10.7150/ijms.16185

41. Islam MM, Iqbal U, Walther B, Atique S, Dubey NK, Nguyen PA, et al. Uso de benzodiazepínicos e risco de demência na população idosa: uma revisão sistemática e meta-análise. Neuroepidemiologia. 2016;47(34):181-91. https://doi.org/10.1159/000454881

42. Markota M, Rummans TA, Bostwick JM, Lapid MI. Uso de benzodiazepínicos em adultos mais velhos: perigos, manejo e terapias alternativas. Mayo Clin Proc. 2016;91(11):1632-9. https://doi.org/10.1016/j.mayocp.2016.07.024

43. Picton JD, Marino AB, Nealy KL. Uso de benzodiazepínicos e declínio cognitivo em idosos. Am J Health Syst Pharm. 2018;75(1):e6-e12. https:// doi.org/10.2146/ajhp160381

44. Reid M, Parkinson L, Gibson R, Schofield P, D'Este C, Attia J, et al. Memory complaint questionnaire performed poorly as screening tool: validation against psychometric tests and affective measures. J Clin Epidemiol. 2012;65(2):199-205. https://doi.org/10.1016/j.jclinepi.2011.06.006

45. Ferri CP, Prince M, Brayne C, Brodaty H, Fratiglioni L, Ganguli M, et al. Alzheimer's Disease International. Global prevalence of dementia: a Delphi consensus study. Lancet. 2005;366(9503):2112-7. https://doi. org/10.1016/S0140-6736(05)67889-0 